\title{
ANALISIS VARIABEL PEMILIHAN JALAN TOL SEGMEN BAWEN-SALATIGA
}

\author{
Dewi Handayani ${ }^{1)}$, Amirotul $\mathrm{MHM}^{2)}$, dan Revina Anggraeni Primasari ${ }^{3)}$ \\ 1) Pengajar Fakultas Teknik, Prodi Teknik Sipil, Universitas Sebelas Maret \\ 2) Pengajar Fakultas Teknik, Prodi Teknik Sipil, Universitas Sebelas Maret \\ 3) Mahasiswa Fakultas Teknik, Prodi Teknik Sipil, Universitas Sebelas Maret \\ J1. Ir. Sutami 36A, Surakarta 57126; Telp. 0271-634524. Email: mrevinaa@ gmail.com
}

\begin{abstract}
The toll road connecting Semarang to Solo is a part of Trans Java Toll road which plays an important role in spinning the wheel of economy. According to PT Trans Mega of central Java as the company handling the project of Semarang-Solo toll, the segments of toll are divided into 5 sections, and one of them is Bawean-Salatiga segment which is located in the $3^{\text {rd }}$ section. The length of Bawean-Salatiga toll segment is longer than that of non-toll, but the possibility to choose toll road is still there since the speed allowed on the toll road is faster than that of non-toll road, though the difference of time taken is only maximally 10 minutes. Accordingly, it is necessary to be studied as regards what variables influence the users so that they choose Bawean-Salatiga toll. The primary data are gained from the results of stated preference questionnaire distributed to the class 1 vehicle users, and they have ever passed through the segment of Bawean-Salatiga toll. The utility value of those results is analyzed by employing binary logistic regression. Furthermore, statistical tests for $\left(\mathrm{R}^{2}\right.$, chi-square, and the overall percentages) are executed to find out whether the related variables that are researched are significant for the independent variable or not. The researched variables are transportation costs and time of the trip. Viewed from the aspects of costs and time, those aspects are not advantageous to the users. However, there are several respondents who take into account other variables so that they eventually decide to take the toll road. Other variables that trigger the users to take Bawean-Salatiga toll road are those associated with traffic condition, safety, landscape, and toll road geometry.
\end{abstract}

Key words: Stated Preference, Binary Logistic Regression, Transportation Costs, Time Travel

\begin{abstract}
Abstrak
Jalan tol Semarang-Solo merupakan bagian dari jaringan Jalan Tol Trans Jawa yang mempunyai peran penting dalam menjalankan roda perekonomian. Berdasarkan PT Trans Marga Jateng selaku perusahaan pengelola proyek Tol Semarang-Solo membagi ruas tol menjadi 5 seksi, salah satunya yaitu ruas Bawen-Salatiga yang terletak pada Seksi 3. Panjang tol segmen Bawen-Salatiga lebih besar daripada jalan non tol, akan tetapi kemungkinan memilih jalan tol tetap ada karena kecepatan di jalan tol lebih besar dibandingkan jalan non tol, walaupun selisih waktu tempuh paling banyak sebesar 10 menit. Maka perlu diteliti variabel apakah yang mempengaruhi pengguna memilih Jalan Tol Bawen-Salatiga. Data primer didapat dari hasil kuisioner stated preference yang diajukan kepada pengguna kendaraan golongan I dan sudah pernah melewati segmen Jalan Tol Bawen-Salatiga. Hasil tersebut dianalisis nilai utilitasnya dengan persamaan regresi logistik biner, kemudian dilakukan uji statistik (uji $\mathrm{R}^{2}$, uji chi-square, uji overall percentage) untuk mengetahui variabel terikat yang diteliti signifikan terhadap variabel bebas atau tidak. Variabel yang diteliti yaitu biaya transportasi dan waktu tempuh. Dilihat dari segi biaya dan waktu, hal tersebut tidak menguntungkan pengguna, tetapi terdapat beberapa responden yang mempertimbangkan variabel lain sehingga tetap memilih jalan tol. Variabel yang mungkin membuat pengguna memilih jalan tol Bawen-Salatiga yaitu variabel berdasarkan kondisi lalu lintas, safety, lanscape dan geometri jalan tol.
\end{abstract}

Kata Kunci: Stated Preference, Regresi Logistik Biner, Biaya Transportasi, Waktu Tempuh

\section{PENDAHULUAN}

Pertumbuhan penduduk dan perkembangan perekonomian di daerah Jawa Tengah cukup tinggi mengakibatkan aktivitas dan pergerakan warga semakin meningkat. Seiring dengan pertumbuhan dan perkembangan ekonomi maka berdampak pada peningkatan pergerakan dan angka lalu lintas harian, bahkan padatnya lalu lintas daerah Jawa Tengah tidak bisa dihindari khususnya jalan penghubung antar Semarang dan Solo. Pembangunan jalan penghubung tersebut dilatarbelakangi oleh kebutuhan masyarakat akan transportasi yang mudah dan cepat. Jalan tol Semarang-Solo sepanjang 75,67 km ini menghubungkan Kota Semarang, Salatiga, dan Surakarta serta melewati 3 kabupaten, yaitu Kabupaten Semarang, Kabupaten Boyolali, dan Kabupaten Sukoharjo. Jalan Tol Bawen-Salatiga termasuk segmen dari Jalan Tol Semarang-Solo dengan panjang $20,7 \mathrm{~km}$. Penelitian ini ditujukan untuk mengetahui variabel pemilihan Jalan Tol Segmen Bawen-Salatiga berdasarkan presepsi pengguna dengan Metode Stated Preference. Metode stated preference sudah cukup familiar untuk penelitian jalan tol, seperti pada penelitian Teofani Rizkhy N. (2017), Ade Yudha Iswara (2017), Hera Cahyaning P. (2018), dan Ongki Pranata (2018). Nilai utilitas pemilihan jalan tol diolah menggunakan regresi logistik biner seperti penelitian Juita Elena (2014), Andi Hadid S.N.D. (2014), M. Arif Wibowo (2018), dan 
Roizan Intifada (2018). Berdasarkan literatur yang direview, variabel-variabel yang mempengaruhi pemilihan jalan tol yaitu: waktu tempuh, biaya perjalanan (tarif), kemudahan rute, kecelakaan fatal, endogen (efektivitas layanan jalan tol), dan eksogen (kualitas reliability, responsiveness, assurance, empatby, dan tangible). Dari sekian banyak studi, variabel yang mendominasi dan signifikan hasilnya yaitu waktu tempuh dan biaya perjalanan (tarif). Semua rujukan yang menganalisis variabel tersebut, hasilnya signifikan terhadap pemilihan jalan tol. Tarif tol merupakan variabel yang sering dianalisis, namun pada penelitian ini yang diuji signifikansinya yaitu variabel waktu tempuh dan biaya transportasi,

\section{DASAR TEORI}

\section{Jalan Tol}

Menurut PP No. 15 Tahun 2005 dijelaskan bahwa definisi jalan tol adalah jalan umum yang merupakan bagian sistem jaringan jalan dan sebagai jalan nasional yang penggunaannya diwajibkan membayar tol. Jalan tol diselenggarakan dengan maksud untuk mempercepat pewujudan jaringan jalan dengan sebagian atau seluruh pendanaan berasal dari pengguna jalan untuk meringankan beban pemerintah.

\section{Analisis Pemilihan Rute}

Analisis ini digunakan untuk menjelaskan bagaimana proses pemilihan rute pengguna jalan dari setiap pergerakan utnuk masing-masing pasangan zona asal dan tujuan. Setiap pengendara akan memiliki kecenderungan untuk memilih: Rute yang meminimumkan biaya perjalanan, Rute tercepat (apabila pengendara lebih mementingkan waktu dibandingkan jarak dan biaya), Rute yang lebih kecil pengeluaran biayanya (apabila pengendara keberatan untuk mengeluarkan biaya lebih), Rute yang terhindar dari kemacetan. Terdapat beberapa faktor yang menjadi dasar dalam pemilihan rute yaitu: perbedaan persepsi mengenai biaya transportasi, perbedaan informasi tentang kondisi lalu lintas, adanya fluktuasi kemacetan pada setiap jam maupun hari, kondisi jalan, situasi lingkungan, dan jenis kendaraan.

\section{Biaya Transportasi (Transport Costs)}

Biaya transportasi adalah biaya yang harus ditanggung oleh pengguna transportasi dalam proses transportasi. Biaya transportasi juga terdiri dari biaya tetap/ infrastruktur dan biaya variabel/ operasi (Jean, 2013).

1. Biaya Tetap/ Infrastuktur

Biaya tetap merupakan biaya yang secara keseluruhan tidak berubah sekalipun mengalami aktivitas yang meningkat ataupun menurun.

2. Biaya Variabel/ Operasi

Biaya variabel merupakan biaya yang akan mengalami perubahan secara proporsional sesuai dengan aktivitas yang dilakukan.

\section{Stated Preference}

Stated Preference dicirikan dengan adanya penggunaan desain eksperimen untuk membangun alternatif hipotesa terhadap situasi (bypothetical situation) yang kemudian disajikan kepada responden. Selanjutnya responden ditanya mengenai pilihan apa yang mereka inginkan untuk melakukan sesuatu atau bagaimana mereka membuat rating/ ranking atau pilihan tertentu di dalam satu atau beberapa situasi dugaan (Ortuzar and Willumsen, 2007).

\section{Analisis Utilitas}

Utilitas merupakan ukuran istimewa sesorang dalam menentukan pilihan alternatif terbaiknya atau suatu yang dimaksimumkan oleh setiap individu (Tamin, 2000). Utilitas dapat dideskripsikan sebagai kombinasi linier dari atribut dan variabel yang ditinjau dan dimodelkan dengan menggunakan metode regresi liner. Berikut merupakan model yang menunjukkan hubungan linier antara dua jenis variabel, yaitu variabel bebas $(\mathrm{X})$ dan variabel terikat $(\mathrm{Y})$ :

$$
Y=\beta_{0}+\beta_{1} X_{1}+\beta_{2} X_{2}+\ldots+\beta_{n} X_{n}
$$

Dimana:

$\mathrm{Y} \quad=$ peubah tidak bebas (terikat)

$\beta_{0}, \beta_{1}, \ldots, \beta_{\mathrm{n}}=$ konstanta regresi

$\mathrm{X}_{1}, \mathrm{X}_{2}, \ldots, \mathrm{X}_{\mathrm{n}}=$ peubah bebas

\section{Uji Statistik}


Sebuah penelitian yang dilakukan dengan memanfaatkan data statistik, kemudian melakukan suatu uji statistik yang digunakan untuk menguji tingkat kepercayaan (reability) terhadap model yang didapat, yaitu dengan mengukur kemampuannya dalam mengestimasi nilai utilitas. Uji statistik pada penelitian ini meliputi uji koefisien determinasi $\left(\mathrm{R}^{2}\right)$, uji chi-square, dan uji overall percentage.

\section{METODE}

Tahap pertama yang dilakukan adalah memantau google maps selama 1×24 jam untuk mendapatkan data jarak, waktu tempuh, dan kecepatan jalan tol maupun jalan non-tol Bawen-Salatiga. Peneliti juga melakukan survei ke Pom Bensin dan beberapa tempat servis/bengkel mobil di sekitar area UNS Kentingan untuk mendapatkan nilai harga BBM, pelumas dan ban sebagai variabel untuk menentukan nilai Biaya Operasional Kendaraan (BOK). Kemudian mencari nilai biaya transportasi pengguna ketika melewati jalan tol dan jalan non-tol. Nilai biaya transportasi, waktu tempuh, jarak, dan kondisi perjalanan tersebut dimasukkan ke kuisioner untuk ditanyakan ke pengguna jalan tol Bawen-Salatiga. Tahap selanjutnya, peneliti dan beberapa surveyor melakukan wawancara di lokasi survei untuk mendapatkan jawaban responden terhadap kuisioner dengan metode stated preference yang diberikan, supaya dapat diolah menjadi data primer. Setelah pengambilan data dari responden sudah memenuhi syarat jumlah sampel, data tersebut kemudian dianalisis untuk mendapatkan persamaan utilitas kemudian dianalisis dengan uji statistik.

\section{HASIL DAN PEMBAHASAN}

Penitian ini menguji variabel/atribut biaya transportasi dan waktu tempuh. Setiap atribut dibuat ke dalam 2 pemilihan jalan yang berbeda yaitu perjalanan melalui jalan tol dan jalan non-tol. Atribut biaya transportasi dan waktu tempuh jalan non tol, masing-masing dibagi menjadi 2 level yaitu pada saat kondisi lancar $(51 \mathrm{~km} / \mathrm{jam})$ dan tidak lancer $(38$ $\mathrm{km} / \mathrm{jam}$ ). Sedangkan untuk atribut biaya transportasi dan waktu tempuh jalan tol, masing-masing dibagi menjadi 2 level yaitu saat kondisi sangat lancar $(100 \mathrm{~km} / \mathrm{jam})$ dan lancar $(80 \mathrm{~km} / \mathrm{jam})$.

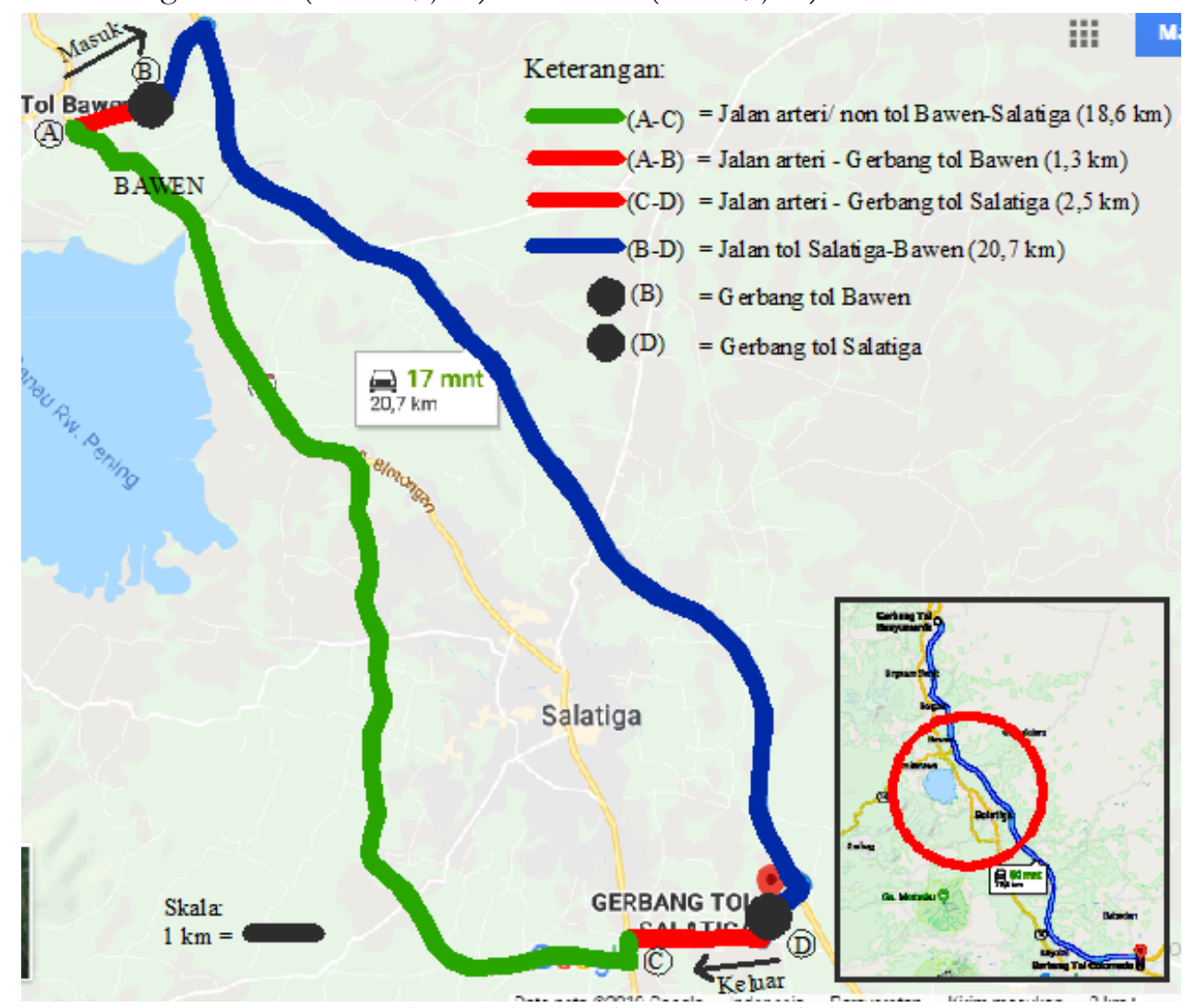

Gambar 1. Sketsa Jalan Bawen-Salatiga

Berdasarkan Gambar 1, jalan non tol Bawen-Salatiga terletak pada titik A-C sepanjang 18,6 km dan jalan tol BawenSalatiga terletak pada titik B-D sepanjang $20,7 \mathrm{~km}$. Jalan akses untuk masuk gerbang tol Bawen terletak pada titik A-B 
sepanjang 1,3 km dan jalan akses untuk keluar gerbang tol Salatiga terletak pada titik D-C sepanjang 2,5 km. Biaya transportasi terdiri dari biaya tetap/infrastruktur dan Biaya Operasional Kendaraan (BOK). Perhitungan BOK menggunakan rumus Pasific Consultant International (PCI). Penelitian ini hanya memperhitungkan biaya langsung kendaraan yaitu biaya konsumsi BBM, biaya konsumsi oli mesin, dan biaya konsumsi pemakaian ban kendaraan. Biaya transportasi pada jalan non tol sama dengan nilai BOK jalan non tol karena tidak dikenakan tarif (biaya infrastruktur). Berikut hasil perhitungan biaya transportasi jalan tol dan jalan non tol Bawen-Salatiga:

Tabel 1. Perhitungan Biaya Operasional Kendaraan (BOK) Jalan Non Tol Bawen-Salatiga

\begin{tabular}{|c|c|c|c|c|c|c|}
\hline \multirow{2}{*}{ Kecepatan } & \multicolumn{3}{|c|}{ BOK (Rp/km) } & \multirow{2}{*}{$\begin{array}{c}\text { Jarak } \\
(\mathrm{km})\end{array}$} & \multirow{2}{*}{$\begin{array}{c}\text { BOK } \\
(\mathrm{Rp} / \mathrm{km})\end{array}$} & \multirow{2}{*}{$\begin{array}{l}\text { BOK Total } \\
\text { (Rp) }\end{array}$} \\
\hline & BBM & Pelumas & Ban & & & \\
\hline $51 \mathrm{~km} /$ jam (lancar) & 684,97 & 74,99 & 30,79 & \multirow{2}{*}{18,6} & 791 & 14708 \\
\hline $38 \mathrm{~km} /$ jam (tidak lancar) & 820,14 & 81,93 & 23,66 & & 926 & 17218 \\
\hline
\end{tabular}

Tabel 2. Perhitungan Biaya Operasional Kendaraan (BOK) Jalan Akses

\begin{tabular}{|c|c|c|c|c|c|c|}
\hline \multirow{2}{*}{ Kecepatan } & \multicolumn{3}{|c|}{ BOK $(\mathrm{Rp} / \mathrm{km})$} & \multirow{2}{*}{$\begin{array}{l}\text { Jarak } \\
(\mathrm{km})\end{array}$} & \multirow{2}{*}{$\begin{array}{c}\text { BOK } \\
(\mathrm{Rp} / \mathrm{km})\end{array}$} & \multirow{2}{*}{$\begin{array}{c}\text { BOK Total } \\
\text { (Rp) }\end{array}$} \\
\hline & BBM & Pelumas & Ban & & & \\
\hline $39 \mathrm{~km} /$ jam (titik A-B) & 804,51 & 81,09 & 24,21 & 1,3 & 910 & 1183 \\
\hline $30 \mathrm{~km} / \mathrm{jam}$ (titik C-D) & 976,48 & 90,48 & 19,27 & \multirow[b]{2}{*}{2,5} & 1086 & 2716 \\
\hline $22 \mathrm{~km} /$ jam (titik C-D) & 1188,58 & 102,28 & 14,88 & & 1306 & 3264 \\
\hline
\end{tabular}

Sumber: Analisis Data (2019)

Tabel 3. Perhitungan Biaya Operasional Kendaraan (BOK) Jalan Tol Bawen-Salatiga

\begin{tabular}{|c|c|c|c|c|c|c|}
\hline \multirow{2}{*}{ Kecepatan } & \multicolumn{3}{|c|}{ BOK $(\mathrm{Rp} / \mathrm{km})$} & \multirow{2}{*}{$\begin{array}{l}\text { Jarak } \\
(\mathrm{km})\end{array}$} & \multirow{2}{*}{$\begin{array}{c}\text { BOK } \\
(\mathrm{Rp} / \mathrm{km})\end{array}$} & \multirow{2}{*}{$\begin{array}{c}\text { BOK Total } \\
\text { (Rp) }\end{array}$} \\
\hline & BBM & Pelumas & Ban & & & \\
\hline $100 \mathrm{~km} / \mathrm{jam}$ (sangat lancar) & 1151,86 & 100,52 & 57,67 & \multirow{2}{*}{20,7} & 1310 & 27118 \\
\hline $80 \mathrm{~km} /$ jam (lancar) & 702,65 & 71,84 & 46,7 & & 821 & 16999 \\
\hline
\end{tabular}

Kecepatan dan jarak dari jalan non tol dan jalan akses didapatkan dari pemantauan google maps, sedangkan kecepatan pada jalan tol diambil sesuai dengan kecepatan yang sering terjadi di lapangan. Penelitian ini memperhitungkan BOK jalan akses yang juga akan berpengaruh bagi pengguna jalan tol. Maka, biaya transportasi pada jalan tol didapat dari BOK tol dan BOK jalan akses untuk menuju dan keluar dari jalan tol, ditambah lagi dengan tarif tol.

Kesimpulan:

- Biaya transportasi jalan non tol saat kondisi lancar $=\mathrm{Rp} 14.708 \approx \mathrm{Rp} 15.000$

- Biaya transportasi jalan non tol saat kondisi tidak lancar $=\mathrm{Rp} 17.218 \approx \mathrm{Rp} 18.000$

- Biaya transportasi jalan tol saat kondisi sangat lancar $(100 \mathrm{~km} / \mathrm{jam})$

$$
\text { BT Total Jalan Tol }=\operatorname{Rp} 27.118+\operatorname{Rp} 1.183+\mathrm{Rp} 2.716+\mathrm{Rp} 17.500=\mathrm{Rp} 48.516 \approx \mathrm{Rp} 49.000
$$

- Biaya transportasi jalan tol saat kondisi lancar $(80 \mathrm{~km} / \mathrm{jam})$

BT Total Jalan Tol $\quad=\operatorname{Rp} 16.999+\mathrm{Rp} 1.183+\mathrm{Rp} 3.264+\mathrm{Rp} 17.500=\mathrm{Rp} 38.946 \approx \mathrm{Rp} 39.000$

Pada penelitian ini, penentuan waktu tempuh dilakukan melalui pendataan menggunakan aplikasi google maps. Berikut ini variasi waktu tempuh pada jalan tol dan jalan non-tol:

Tabel 4. Variasi Waktu Tempuh Jalan Bawen-Salatiga

\begin{tabular}{ccc}
\hline & Kondisi Lalu Lintas & Waktu (menit) \\
\hline \multirow{2}{*}{ Jalan Non Tol } & Lancar & 22 \\
\cline { 2 - 3 } & Tidak Lancar & 30 \\
\hline \multirow{2}{*}{ Jalan Tol } & Sangat Lancar & 20 \\
\cline { 2 - 3 } & Lancar & 25 \\
\hline
\end{tabular}

Sumber: Analisis Data (2019)

Berdasarkan kesimpulan biaya transportasi dan nilai waktu tempuh diatas, dapat dibuat skenario perjalanan.

Tabel 5. Skenario Perjalanan Bawen-Salatiga 


\begin{tabular}{cccc}
\hline & Kondisi Lalu Lintas & Biaya Perjalanan & Waktu Tempuh \\
\hline \multirow{2}{*}{ Jalan Non Tol } & Lancar & $\operatorname{Rp~} 15.000(+)$ & 22 menit $(+)$ \\
\cline { 2 - 4 } & Tidak Lancar & $\operatorname{Rp~} 18.000(-)$ & 30 menit $(-)$ \\
\hline \multirow{2}{*}{ Jalan Tol } & Sangat Lancar & $\operatorname{Rp~49.000(+)~}$ & 20 menit $(+)$ \\
\cline { 2 - 4 } & Lancar & $\operatorname{Rp~39.000(-)~}$ & 25 menit $(-)$ \\
\hline
\end{tabular}

Sumber: Analisis Data (2019)

Alternatif situasi perjalanan diperoleh dengan desain faktorial (Full Factorial Design) yang mengkombinasikan level dengan atribut, maka didapatkan 16 kemungkinan yang akan diolah menjadi skenario. Setelah diolah, terdapat 4 skenario yang menunjukkan bahwa waktu tempuh jalan non tol lebih cepat 3 menit daripada jalan tol. Hal tersebut dapat terjadi karena beberapa faktor, salah satunya yaitu selisih panjang jalan tol yang cukup jauh berbeda dengan jalan non tol. Jalan non tol Bawen-Salatiga sepanjang 18,6 km, sedangkan panjang jalan tol Bawen-Salatiga ditambah dengan jalan aksesnya menjadi sepanjang $24,5 \mathrm{~km}$. Skenario tersebut dihilangkan karena secara logika itu tidak masuk akal, pengguna harus mengeluarkan biaya lebih banyak dan waktu tempuhnya lebih lama ketika melewati tol, tetapi kondisi tersebut tetap dipertanyakan ke responden hanya untuk melihat apakah ada variabel lain yang dipertimbangkan untuk menggunakan jalan tol selain waktu dan biaya transportasi.

Tabel 6. Skenario yang Membandingkan Kondisi Jalan Tol Lancar dan Jalan Non Tol Lancar

JALAN TOL: Bawen-Salatiga $(20,7 \mathrm{~km})$

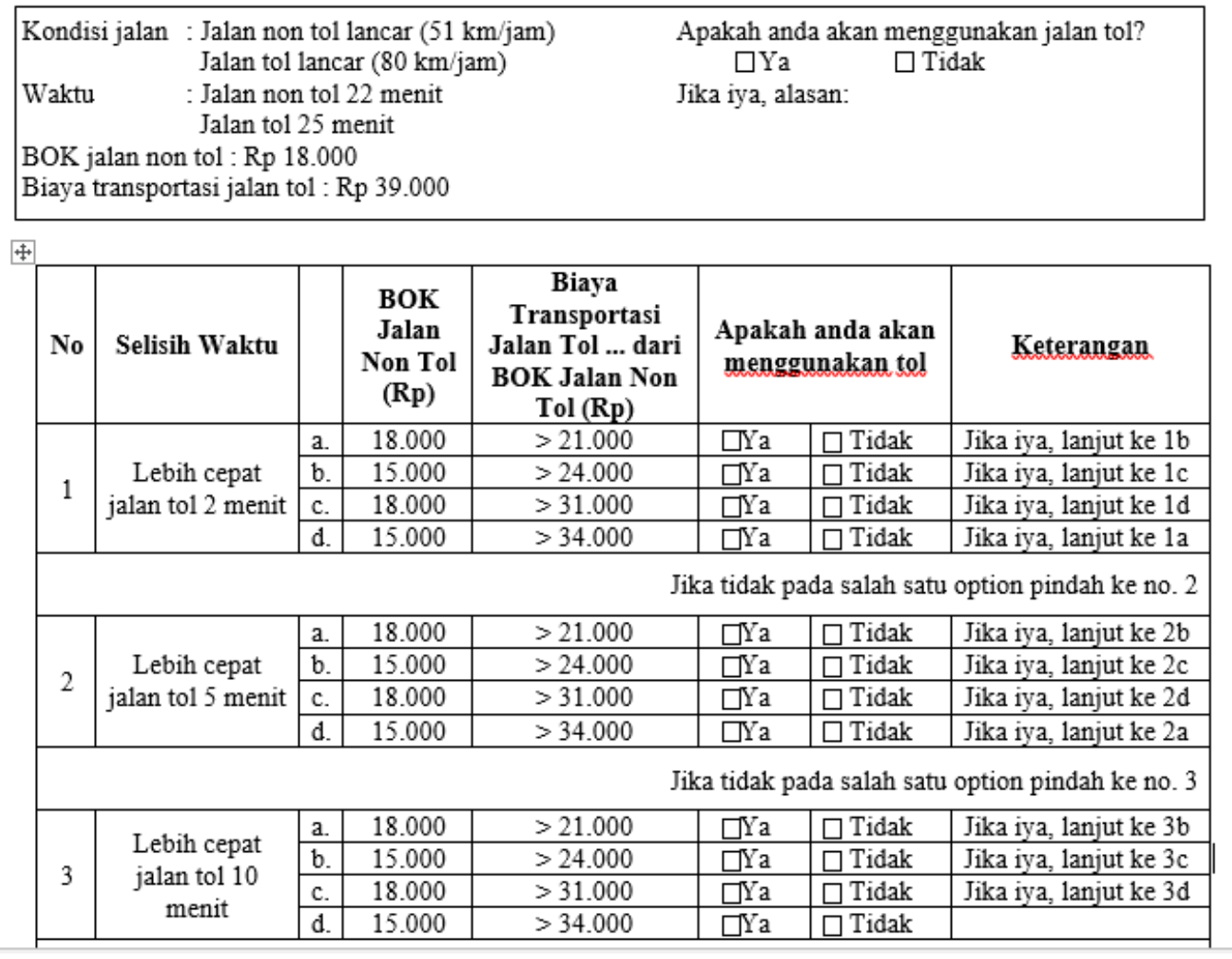

Sumber: Analisis Data (2019)

\section{Analisis Data Karakteristik Responden Pengguna Jalan Tol}

Analisis karakteristik reponden dikelompokkan menjadi tiga berdasarkan jenis kelamin, usia, dan pekerjaan.

a. Analisis Data Karakteristik Responden Berdasarkan Jenis Kelamin

Variasi responden berdasarkan jenis kelamin yang diolah datanya pada penelitian ini ditunjukkan pada Tabel 7. berikut:

Tabel 7. Jumlah Responden dengan Karakteristik Pengguna Jalan Tol Berdasarkan Jenis Kelamin

Jenis Kelamin Jumlah Presentase




\begin{tabular}{ccc}
\hline Laki-laki & 67 & $78 \%$ \\
\hline Perempuan & 19 & $22 \%$ \\
\hline Jumlah & 86 & $100 \%$ \\
\hline \multicolumn{2}{l}{ Sumber: Analisis Data (2019) }
\end{tabular}

b. Analisis Data Karakteristik Responden Berdasarkan Usia

Badan Pusat Statistik merupakan lembaga pemerintahan yang bergerak dibidang statistik mengklasifikasikan usia ke dalam beberapa kelompok seperti pada Tabel 8. berikut:

Tabel 8. Klasifikasi Usia Berdasarkan Badan Pusat Statistik (BPS)

$\frac{\frac{\frac{\text { Klasifikasi Usia (Tahun) }}{15-24}}{25-54}}{\frac{>54}{\text { Sumber: Badan Pusat Statistik (BPS) }}}$

Variasi responden berdasarkan usia menurut hasil survei utama ditunjukkan seperti pada Tabel 9. berikut ini:

Tabel 9. Jumlah Responden dengan Karakteristik Pengguna Jalan Tol Berdasarkan Usia

\begin{tabular}{ccc}
\hline Usia (Tahun) & Jumlah & Presentase \\
\hline $15-24$ & 35 & $41 \%$ \\
\hline $25-54$ & 39 & $45 \%$ \\
\hline$>54$ & 12 & $14 \%$ \\
\hline Jumlah & 86 & $100 \%$ \\
\hline Sumber: Analisis Data (2019) &
\end{tabular}

c. Analisis Data Karakteristik Responden Berdasarkan Profesi

Keragaman responden berdasarkan profesi dapat ditunjukkan seperti pada Tabel 10. berikut:

Tabel 10. Jumlah Responden dengan Karakteristik Pengguna Berdasarkan Profesi

\begin{tabular}{ccc}
\hline Profesi & Jumlah & Presentase \\
\hline Karyawan Swasta & 18 & $21 \%$ \\
\hline PNS & 2 & $2 \%$ \\
\hline Ibu Rumah Tangga & 4 & $5 \%$ \\
\hline Pensiunan & 5 & $6 \%$ \\
\hline Wiraswasta & 18 & $22 \%$ \\
\hline Pelajar/Mahasiswa & 28 & $33 \%$ \\
\hline Guru/Dosen & 8 & $9 \%$ \\
\hline Polisi & 1 & $1 \%$ \\
\hline TNI & 1 & $1 \%$ \\
\hline Jumlah & 86 & $100 \%$ \\
\hline
\end{tabular}

Sumber: Analisis Data (2019)

\section{Analisis Utilitas Pemilihan Rute Jalan Tol}

Nilai koefisien didapat dari perhitungan selisih masing-masing variabel yang digunakan. Nilai selisih tersebut adalah nilai $\beta 1$ dan $\beta 2$. $\beta 1$ adalah selisih biaya transportasi jalan tol dengan jalan non tol $\left(C_{t}-C_{n t}\right)$ dan $\beta 2$ adalah selisih waktu tempuh jalan tol dengan jalan non tol $\left(T_{t}-T_{n t}\right)$, sehingga didapatkan nilai variabel pembentuk utilitas regresi linier berganda $\left(\mathrm{U}_{\text {tol-non tol }}\right)$.

$$
\mathrm{U}_{\text {tol-non tol }}=0,605-0,081\left(\mathrm{C}_{\mathrm{t}}-\mathrm{C}_{\mathrm{nt}}\right)-0,128\left(\mathrm{~T}_{\mathrm{t}}-\mathrm{T}_{\mathrm{nt}}\right)
$$

\section{Uji Statistik}

Setelah mendapatkan nilai utilitas selanjutnya dilakukan uji statistik terhadap model dengan bantuan software statistik.

1. Uji Koefisien Determinasi $\left(\mathrm{R}^{2}\right)$

Berdasarkan perhitungan software statistik menunjukkan nilai Nagelkerke R Square sebesar 0,095. Nilai ini kemudian dianalogikan menjadi nilai $\mathrm{R}^{2}$ menggunakan grafik pemetaan pseudo- $\mathrm{R}^{2}$ terhadap linear $\mathrm{R}^{2}$, sehingga menghasilkan 
$\mathrm{R}^{2}$ sebesar $28 \%$. Hal itu menjelaskan bahwa pengaruh variabel terikat yang diteliti terhadap utilitas pengguna jalan tol Bawen-Salatiga hanya sebesar $28 \%$.

2. Uji Chi-Square

Uji Chi-Square memperoleh hasil signifikansi sebesar 0,998. Hasil tersebut dapat ditarik kesimpulan dari hipotesis yang ada bahwa penambahan variabel yang diteliti tidak mempengaruhi terhadap model. Variabel biaya transportasi dan waktu tempuh bukan variabel penentu pemilihan jalan tol jalan tol Bawen-Salatiga., maka variabel tersebut tidak mempengaruhi nilai utilitas.

3. Uji Overall Percentage

Hasil uji Overall Percentage menunjukkan kesesuaian antara model dengan hasil survei. Kesesuaian antara perhitungan model dan hasil survei sebesar 16,2\% untuk responden yang menjawab "iya" memilih jalan tol. Kesesuaian antara perhitungan model dan hasil survei sebesar $95,1 \%$ untuk responden yang menjawab "tidak" memilih jalan tol.

\section{Analisis responden Memilih Rute Jalan Tol}

Berdasarkan Tabel 6, terdapat responden menjawab "iya" yang berarti memilih melewati jalan tol. Dari 86 responden, terdapat 10 responden yang mau menggunakan jalan tol. 10 responden tersebut memberikan alasan untuk tetap memilih jalan tol. Berikut ini alasan pengguna tetap memilih jalan tol:

Tabel 11. Alasan Pengguna Memilih Jalan Tol

\begin{tabular}{cccc}
\hline Responden & Usia (Tahun) & Pekerjaan & Alasan Memilih Jalan Tol \\
\hline 1 & 55 & Ibu Rumah Tangga & Nyaman, tidak macet, lancar \\
\hline 2 & 38 & Dosen & Nyaman, lancar \\
\hline 3 & 60 & Pensiunan & Jalan non tol lebih beresiko kecelakaan \\
\hline 4 & 22 & Wiraswasta & Jalan dan fasilitas lebih enak tol \\
\hline 5 & 55 & Karyawan Swasta & Pemandangan jalan tol indah \\
\hline 6 & 41 & Wiraswasta & Lebih praktis, nyaman cepat, fasilitas lebih enak \\
\hline 7 & 22 & Karyawan Swasta & Jalan non tol lebih ramai, jalan tol tidak ada kendaraan bermotor \\
\hline 8 & 25 & Mahasiswa & Jalan tol lebih enak karena jalannya lurus dibandingkan jalan non tol yang \\
banyak belokan dan lubang
\end{tabular}

Sumber: Analisis Data (2019)

Banyak pertimbangan pengguna jalan untuk memilih melewati jalan tol, tidak hanya melihat dari sisi biaya dan waktu. Kondisi jalan tol yang lancar, tidak ada kendaraan bermotor, dan jalan non tol yang lebih beresiko kecelakaan dapat dikategorikan ke alasan responden berdasarkan kondisi lalu lintas. Perihal kenyamanan, fasilitas lebih enak, pandangan lebih luas, jalan tol yang tidak banyak belokan dan tidak ada yang berlubang dikategorikan ke alasan responden memilih jalan tol dari segi lanscape dan geometri. Sedangkan perihal kenyamanan dikategorikan ke alasan responden memilih jalan tol berdasarkan safety.

Maka kemungkinan variabel lain yang membuat pengguna memilih jalan berdasarkan kondisi lalu lintas, safety, lanscape dan geometri jalan tol. Pertimbangan ini yang mengakibatkan pengguna mau mengeluarkan biaya transportasi lebih besar padahal waktu tempuh yang dikeluarkan lebih lama.

\section{SIMPULAN}

Berdasarkan hasil penelitian dan pembahasan, dapat disimpulkan bahwa:

1. Ketiga uji statistik memiliki kesesuaian yaitu variabel biaya transportasi dan waktu tempuh yang diteliti bukan variabel penentu pemilihan jalan tol Bawen-Salatiga. Maka variabel tersebut tidak signifikan terhadap nilai utilitas (nilai Y)/ tidak memenuhi syarat statistik untuk utilitas.

2. Variabel yang mungkin membuat pengguna memilih jalan tol Bawen-Salatiga yaitu variabel berdasarkan kondisi lalu lintas, safety, lanscape dan geometri jalan tol.

\section{REFERENSI}


Ardhian, Radityo, Sagita, Ronny. 2005. Perencanaan Jalan Tol Semarang-Kendal. Semarang: Universitas Diponegoro.

Badan Pengatur Jalan Tol. 2017. http:/ / bpjt.pu.go.id/. Diakses pada tanggal 8 November 2018.

Ben-Akiva, M., Lerman, S.R. 1985. Discrete Choice Analysis: Theory and Application to Travel Demand. Cambridge: The MIT Press.

Breidert, C. 2005. Estimation of Willingness to Pay: Theory, Measurment, Application. Wirtschafts Universtat Wien. Doctoral Thesis.

Departemen Pekerjaan Umum. 1997. Manual Kapasitas Jalan Indonesia (MKJI). Jakarta: Swearod \& Bina Karya.

Djoeddawi, A.H.S.N., Anwar, R., Kusumaningrum, R. 2014. Model Pemiliban Moda antara Kereta Api dan Bus Rute Makassar-Parepare dengan Menggunakan Metode Stated Preference. Malang: Universitas Brawijaya.

Elena, J., O'Connell, L., Anuar, K.A., 2014. For Whom The Tunnel be Tolled: A Four-Factor Model For Explaining Willingnessto-Pay Tolls. USA: Old Dominion University.

Garrod, G., Willis, K.G. 1999. Economic V aluation of The Environment: Methods and Case Studies. United Kingdom: Edward Elgar.

Hensher, D.A., Rose, J.M., Greene, W.H. 2005. Applied Choice Analysis: A Primer. New York: Cambridge University Press.

Hosmer, D. dan S.Lemeshow. 1989. Applied Logistic Regression. New York: John Wiley Series

Intifada, R., Wicaksono, A., Kusumaningrum, R. 2018. Kajian Potensi Penumpang Pesawat Terbang Rute Banyuwangi-Malang Dengan Menggunakan Metode Stated Preference. Malang: Universitas Brawijaya.

Iswanto, D., 2013. Mengkaji Fungsi Keamanan dan Kenyamanan Bagi Pejalan Kaki di Jalur Pedestrian (Trotoar) Jalan Ngesrep Timur $V$ Semarang. Semarang: Universitas Diponegoro.

Iswara, A.Y., Husein, F., Djakfar, L., Bowoputro, H. 2017. Kajian Potensi Pengguna Jalan Tol Malang-Kepanjen. Malang: Universitas Brawijaya.

Jasa Marga. Layanan Jalan Tol, http://mww.jasamarga.com/public/id/infolayanan/infolayanan.aspx, diakses tanggal 12 Maret 2019.

Kroes, E.P., Sheldon, R.J. 1988. Stated Preference Methods: An Introduction. Journal of Transport Economics and Policy. Vol XXII. 11-25.

Kusumananti, P.D. 2018. Studi Willingness to Pay Pengguna jalan Terhadap Tarif Tol Solo-Ngawi. Surakarta: Universitas Sebelas Maret.

Lembaga Pengabdian Kepada Masyarakat Institut Teknologi Bandung. 1997. Study Kelayakan Proyek Transportasi. Bandung: Institut Teknologi Bandung.

Miro, F. 2005. Perencanaan Transportasi. Jakarta: Erlangga.

Novyana, T.R., dkk. R. 2017. Analisis Pentoensi Pengguna Rencana Tol Kediri-Nganjuk Menggunakan Metode Stated Preference. Malang: Universitas Brawijaya.

Nugraha, J., Guritno, S., Kartiko, S.H. 2006. Discrete Choice Models and Logistic Regression. Yogyakarta: Universitas Negeri Yogyakarta.

Ortuzar, J.D., Willumsen, L.G. 2001. Modelling Transport, Third Edition. England: John Wiley \& Sons.

Parabita, Dara, A., Nugraheni, Eny, T. 2007. Evaluasi Kinerja dan Analisa Operasional Lalu Lintas pada Kondisi Kelandaian Khusus Terbadap Pengaruh Kendaraan Berat. Semarang: Universitas Diponegoro.

Parikesit, D. 1993. Kemungkinan Penggunaan Teknik Stated Preference dalam Perencanaan Angkutan Umum. Forum Teknik Sipil No II/I-Agustus 1993. Yogyakarta: Universitas Gajah Mada.

Pranata, O., dkk. 2018. Penentuan Tarif Tol Saradan-Kertosono Berdasarkan Analisis ATP dan WTP. Malang: Universitas Brawijaya.

Prasetyanto, D. 2015. Perbandingan Nilai Kesediaan Membayar Menggunakan Pendekatan Stated Preference Contingent Valuation dan Stated Preference Stated Choice. Bandung: Institut Teknologi Nasional.

Putri, H.C. 2018. Sensitivitas Tarif Tol Solo-Ngawi Ruas Kartasura-Palang Joglo Berdasarkan Willingness to Pay (WTP). Surakarta: Universitas Sebelas Maret.

Rahman, R. 2012. Analisa Biaya Operasi Kendaraan (BOK) Angkutan Umum Antar Kota dalam Propinsi Rute Palu-Poso. Palu: Jurnal Universitas Tadulako.

Rodrigue, J.P., Comtois, C., Slack, B. 2017. The Geography of Transport Systems (Fourth Edition). New York: Routledge.

Ryandika. 2011. Analisis Tarif Tol denan Metode Stated Preference Studi Kasus Jalan Tol Jorr II Segmen Serpong - Cinere. Depok: Universitas Indonesia.

Salma, I.A. Susilowati, I. 2004. Analisis Permintaan Objek Wisata Alam Curug Sewu, Kabupaten Kendal dengan Pendekatan Travel Cost. Semarang: Universitas Diponegoro. 
Satriotomo, D. 2011. Efektivitas Layanan Jalan Tol Kota Semarang dalam Memenuhi Kebutuhan Pengguna. Semarang: Universitas Diponegoro Semarang.

Supriyanto, M.A. 2003. Analisis Pemiliban Moda antara Busway dan Kendaraan Pribadi dengan Model Logit-Probit (Studi Kasus Koridor Blok M-Kota). Depok: Universitas Indonesia.

Tamin, O.Z. 2000. Perencanaan dan Pemodelan Transportasi, Jilid 1. Bandung: Institut Teknologi Bandung.

Trans Marga Jateng. 2017. http:/ / wmw.transmargajateng.co.id/. Diakses pada tanggal 12 November 2018.

Wibowo, A.M. Maryati, S., Ansar, Z. 2018. Analisis Peluang Pergeseran Pengguna Jalan Arteri ke Jalan Tol. Sumatra: Institut Teknologi Sumatra.

Wikipedia. Tarif, https://id.wikipedia.org/wiki/Tarif, diakses tanggal 12 Maret 2019.

Yudhanto, A. 2015. Analisis Kelayakan Ekonomi Pembangunan Jalan Tembus Lawang-Batu. Surabaya: Universitas 17 Agustus 1945 Surabaya. 